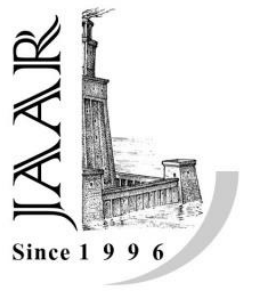

\title{
Impact of Irrigation Deficit on Yield, and Water Productivity of Quinoa
}

Shimaa Khaled ${ }^{1}$, G. Abdel-Nasser², A. H. A. Hussein ${ }^{2}$,Kh. M. Darwish $^{1}$, O. M. Ibrahim ${ }^{3}$

1.Land\& Water Technologies Dept., Arid Lands Cultivation Research Institute, City of Scientific Research and Technological Applications -SART-City, Alexandria, Egypt

2.Soil and Agricultural Chemistry Dept., Faculty of Agriculture Saba Basha, Alexandria University, Alexandria, Egypt

3.Plant Production Dept., City of Scientific Research and Technological Applications SARTCity, Alexandria, Egypt DOI: $10.21608 /$ jalexu.2021.188848

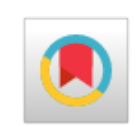

Article Information

Received:July $5^{\text {th }} 2021$

Revised: July $5^{\text {th }} 2021$

Accepted:August $10^{\text {th }} 2021$

Published:August1 1 $1^{\text {st } 2021}$

ABSTRACT: A field experiment was carried out to ivestigat the impact of irrigation deficit on Quinoa (chenopodium quinoa Willd) variety Chipaya. The sowing date was Nov. 11, 2018, and the harvesting date was March. 17, 2019.The irrigation regimes (irrigation deficit) were in the rate of $40,60,80$, and $100 \%$ of the reference evapotranspiration $\left(\mathrm{ET}_{0}\right)$ as compared with rainfed irrigation as control. The experimental design was a Randomized Complete Block Design with three replicates. The results indicated that the irrigation regimes had a significant effect on Quinoa productivity. The best effect of irrigation regimes on the gross seed yield of quinoa was recorded with $100 \%$ of $\mathrm{ET}_{0}$ irrigation regime corresponding to an increase by $155.56 \%$ over the rainfed irrigation. Seed yield reached the highest values of 0.616 ton/fed at $100 \%$ of $\mathrm{ET}_{0}$,.Also, there were no significant differences between irrigation at 100 and $80 \%$ of the $\mathrm{ET}_{0}$ irrigation regime. Seed weight per plant, and per $\mathrm{m}^{2}$ had the highest values with $100 \%$ of $\mathrm{ET}_{0}$. It increased by about 216.70 and $216.68 \%$ over the rainfed irrigation. The total applied water (TAW) were 931.4, 796.6, $658.0,523.3$, and $285.6 \mathrm{~m}^{3} / \mathrm{fed}$ for irrigation treatments of $100,80,60$, and $40 \%$ of $\mathrm{ET}_{0}$ and rainfed irrigation, respectively. The irrigation water-use efficiency (IWUE) or water productivity (WP) as $\mathrm{kg}$ grain $/ \mathrm{m}^{3}$ of applied water reached the values of $0.681,0.655,0.806,0.778$, and $0.712 \mathrm{~kg} / \mathrm{m}^{3}$ for $100,80,60,40 \%$ of $\mathrm{ET}_{0}$, and rain-fed treatments, respectively.Irrigation at 100 or $80 \%$ of $\mathrm{ET}_{0}$ gave the highest seed yield. Nevertheless, irrigation at $60 \%$ of $\mathrm{ET}_{\mathrm{O}}$ gave the highest water productivity (IWUE).

KEYWORDS: Quinoa, rain-fed irrigation, irrigation deficit, seed yield, growth, water productivity, characterization.

\section{INTRODUCTION}

The quinoa plant belongs to the genus Chenopodium and the family Chenopodiaceae.(Iqbal, 2015). It is well adapted to arid and semi-arid regions. It can be planted on high land up to $4000 \mathrm{~m}$ above sea level. Quinoa is a C3 annual dicot of 0.5 to $2 \mathrm{~m}$ height, terminating in a panicle consisting of small flowers, and with only one seed of around $2 \mathrm{~mm}$ produced per flower. (Geerts and Garcia, 2012). Quinoa seed has an excellent balance of carbohydrates, lipids, and protein for nutrition (Maradini-Filho et al., 2017). Quinoa protein has all essential amino acids found in wheat. In addition to lysine and sulfur amino acids (Escuredo et $\boldsymbol{a l}$., 2014). Besides, it contains a considerable amount of fiber and minerals, such as calcium and iron (Ando et al., 2002). Grains of quinoa is used instead of wheat grains in bread and other bakeries production (Abou-Zaid et al., 2012 and Koehler et al., 2014). Quinoa plants are resistant to various stresses such as salinity, cold air, high solar radiation, low temperature, and can be planted in different soil types with the broad range of $\mathrm{pH}$ values (Jacobsen et al., 1998). Drought stress reduces plant growth in terms of shoot and root fresh as well as dry weights along with chlorophyll a and b contents and relative water contents (RWC) while a considerable increase was observed in hydrogen peroxide $\left(\mathrm{H}_{2} \mathrm{O}_{2}\right)$, malondialdehyde (MDA), proline and total sugar contents in some quinoa cultivars (Naz et al., 2020). Under water-scarce conditions, tolerance of plants is highly associated with accumulation of proline, which is an amino acid (non-protein), produces in leaf tissues (Ashraf and Foolad, 2007). Jensen et al. (2000) observed yield reduction when water stress was applied during the flowering stage and grain filling stage, while application of water stress during the vegetative stage led to increased yield. Drought in early vegetative stages may prolong its life cycle, allowing the plant to make up for growth lost 
during the early drought if water is available later. The plant also avoids the negative effects of drought through fast and deep rooting, particularly in dry soils. Quinoa also reduces its leaf area by controlled leaf senescence under drought. The Food and Agriculture Organization of the United Nations (FAO) has identified Quinoa as an important alternative crop to contribute to future global food security and declared the year 2013 as the international year of quinoa (FAO, 2012). Therefore, the present research was conducted to investigate the impact of different irrigation deficits on Quinoa production as compared with rain-fed irrigation.

MATERIALS AND METHODS: 1.The site of the experiment:
The present investigation was carried out at the experimental farm of the City of Scientific Research and Technological Applications SRTACity, Old Borg El-Arab, Alexandria Governorate, Egypt. Geographically, the experimental farm is located at $30^{\circ} 53^{\prime} \mathrm{N}$ and $29^{\circ} 32^{\prime} \mathrm{E}$, with an elevation of about 28 meters above sea level.

\section{Climatic conditions:}

The climatic conditions were extracted from NASA web-meteorological free data (power.larc.nasa.gov) and the new Borg El-Arab station. The values of climatic parameters during the growing season $(2018-2019)$ i.e. temperature $\left(\mathrm{T}{ }^{\circ} \mathrm{C}\right)$, relative humidity $(\mathrm{RH} \%)$, rainfall $(\mathrm{Pe} \mathrm{mm})$, wind speed ( $\mathrm{U} 2 \mathrm{~m} / \mathrm{s}$ at $2 \mathrm{~m}$ height), and atmospheric pressure $(\mathrm{P} \mathrm{kPa})$ are presented in Table (1).

Table (1). Climatological data for the experimental site during the growing season

\begin{tabular}{|c|c|c|c|c|c|c|c|c|}
\hline \multirow[b]{2}{*}{ Months } & \multicolumn{3}{|c|}{ Temperature $\left(\mathrm{C}^{\circ}\right)$} & \multirow[b]{2}{*}{ RH (\%) } & \multirow{2}{*}{$\begin{array}{c}\mathbf{P e} \\
\mathbf{m m}\end{array}$} & \multirow{2}{*}{$\begin{array}{c}\mathbf{U}_{2} \\
\mathrm{~m} / \mathrm{s}\end{array}$} & \multirow{2}{*}{$\begin{array}{c}\mathbf{P} \\
\mathbf{k P a}\end{array}$} & \multirow{2}{*}{$\begin{array}{l}\text { ETo }_{0} \\
\text { mm }\end{array}$} \\
\hline & Max. & Min. & Mean & & & & & \\
\hline Nov. 2018 & 24.46 & 16.06 & 19.69 & 63.13 & 18.74 & 2.62 & 101.16 & 47.03 \\
\hline Dec. 2018 & 19.38 & 12.60 & 15.52 & 67.21 & 33.43 & 3.51 & 101.39 & 63.93 \\
\hline Jan. 2019 & 17.08 & 7.82 & 11.83 & 61.45 & 10.13 & 3.98 & 101.15 & 70.39 \\
\hline Feb. 2019 & 18.79 & 8.78 & 13.15 & 64.22 & 11.71 & 3.29 & 101.25 & 69.62 \\
\hline March & 20.80 & 10.54 & 15.10 & 63.40 & 4.64 & 3.48 & 101.16 & 50.13 \\
\hline
\end{tabular}

\section{Field experiment:}

3.1. Planting The field experiment was planted with a Quinoa crop. Quinoa (chenopodium quinoa Willd) variety Chipaya. The sowing date was Nov. 11, 2018, and the harvesting at Mar.17, 2019. The growing season was 126 days. The soil type was sandy clay loam and some soil physical and chemical properties are illustrated in Table (2). The seeds were sowed in a soil bed with $0.5 \mathrm{~m}$ width and $10.5 \mathrm{~m}$ length with $0.2 \mathrm{~m}$ between plants $(2$ seeds per hole). The number of plants per $\mathrm{m}^{2}$ was 20 plants.

\subsection{Irrigation}

The drip irrigation system was constructed as 0.5 $\mathrm{m}$ between rows and $10.5 \mathrm{~m}$ in length. The irrigation practice was done weekly using a drip irrigation system with a capacity of $6.0 \mathrm{~L} / \mathrm{hr}$.

\subsection{Fertilization}

The experiment was fertilized with recommended doses of ammonium nitrate $(33.5 \% \mathrm{~N})$ as 100 $\mathrm{kg} / \mathrm{fed}$, superphosphate $\left(15.5 \% \mathrm{P}_{2} \mathrm{O}_{5}\right)$ as $50 \mathrm{~kg} / \mathrm{fed}$ and potassium sulfate $\left(48 \% \mathrm{~K}_{2} \mathrm{O}\right)$ as $50 \mathrm{~kg} / \mathrm{fed}$.

\subsection{Experimental treatments}

The experiment was designed to investigate the effect of irrigation regimes as 40,60, 80, and $100 \%$ of the reference evapotranspiration (ET0) as compared with rainfed irrigation. The experimental design was a Randomized Complete Block Design with three replicates.

\section{Soil analysis}

The soil samples were collected from the experimental site at two depths; surface $0-30 \mathrm{~cm}$ and subsurface $30-60 \mathrm{~cm}$ before planting to determine the soil's physical and chemical properties. Soil samples were air-dried and sieved through a $2-\mathrm{mm}$ sieve and analyzed according to the methods described by Carter and Gregorich (2008) and presented in Table (2).

\subsection{Physical properties of soil}

Particle-size distribution is determined by the hydrometer method according to Carter and Gregorich (2008).

\subsection{Chemical properties of soil}

Soil Electrical conductivity (EC) $(1: 1 \mathrm{w} / \mathrm{v})$ was measured using a conductivity meter according to Jackson (1973). Organic carbon OC, Organic Matter OM \%, CaCO3 \%, cations and anions, CEC $\mathrm{meq} / 100 \mathrm{gm}$ soil and available macronutrients NPK (ppm) were laboratory determined according to Jackson (1973), Richards (1972) and Carter and Gregorich (2008).

\section{Water analysis:}

The following parameters of irrigation water were determined; $\mathrm{pH}$, Electrical conductivity (EC), soluble cations ( $\mathrm{Na}, \mathrm{K}, \mathrm{Ca}$, and $\mathrm{Mg}$ ), and soluble anions $\left(\mathrm{CO}_{3}, \mathrm{HCO}_{3}, \mathrm{Cl}\right.$, and $\left.\mathrm{SO}_{4}\right)$ in Table (3). 
(JAAR) Volume: 26 (3)

Table (2). Some soil physical and chemical properties

\begin{tabular}{|c|c|c|}
\hline Soil characteristics & $0-30 \mathrm{~cm}$ & $30-60 \mathrm{~cm}$ \\
\hline \multicolumn{3}{|l|}{ Particle-size distribution( $\%$ ) } \\
\hline Sand $\%$ & 63.05 & 64.11 \\
\hline Silt\% & 16.31 & 15.21 \\
\hline Clay\% & 20.64 & 20.72 \\
\hline Textural Class & SandyClay Loam & SandyClay Loam \\
\hline $\mathrm{pH}(1: 1$, water suspension $)$ & 8.14 & 8.09 \\
\hline EC $(1: 1$, water extract $) \mathrm{dSm}^{-1}$ & 10.00 & 6.00 \\
\hline $\mathrm{CaCO} 3(\%)$ & 48.51 & 48.51 \\
\hline Soil water content (\%) & 3.82 & 3.42 \\
\hline $\mathrm{OM}(\%)$ & 1.34 & 1.57 \\
\hline \multicolumn{3}{|l|}{ Soluble Cations (meq $\mathbf{l}^{-1}$ ) } \\
\hline $\mathrm{Ca}^{++}$ & 10.34 & 7.51 \\
\hline $\mathrm{Mg}^{++}$ & 14.52 & 8.35 \\
\hline $\mathrm{Na}^{+}$ & 73.15 & 41.60 \\
\hline $\mathrm{K}^{+}$ & 2.49 & 2.54 \\
\hline \multicolumn{3}{|l|}{ Soluble Anions (meq $\mathbf{l}^{-1}$ ) } \\
\hline $\mathrm{CO}_{3}^{--}$ & - & - \\
\hline $\mathrm{HCO}_{3}^{-}$ & 8.19 & 7.46 \\
\hline $\mathrm{Cl}^{-}$ & 57.90 & 27.76 \\
\hline $\mathrm{SO}_{4}^{--}$ & 34.01 & 24.93 \\
\hline \multicolumn{3}{|l|}{ Available nutrients mgkg $^{-1}$ soil } \\
\hline Nitrogen $(\mathrm{N})$ & 42.58 & 33.44 \\
\hline Phosphorus (P) & 61.00 & 35.00 \\
\hline Potassium (K) & 600.00 & 500.00 \\
\hline
\end{tabular}

Table (3). Chemical properties of the irrigation water

\begin{tabular}{cc}
\hline Parameters & Value \\
\hline $\mathrm{pH}$ & 8.2 \\
\hline $\mathrm{EC}(\mathrm{dS} / \mathrm{m})$ & 3.6 \\
\hline Soluble cations $(\mathrm{meq} / \mathrm{l})$ & \\
\hline $\mathrm{Ca}^{++}$ & 2.87 \\
\hline $\mathrm{Mg}^{++}$ & 6.56 \\
\hline $\mathrm{Na}^{+}$ & 24.35 \\
\hline $\mathrm{K}^{+}$ & 0.71 \\
\hline Soluble anions $\left(\mathrm{meq}^{+}\right)$ & \\
\hline $\mathrm{CO}_{3}{ }^{--}+\mathrm{HCO}_{3}{ }^{-}$ & 5.25 \\
\hline $\mathrm{Cl}^{-}$ & 13.73 \\
\hline $\mathrm{SO}_{4}^{--}$ & 17.13 \\
\hline Soluble nutrients $(\mathrm{mg} / \mathrm{l})$ & \\
\hline $\mathrm{N}$ & 1.42 \\
\hline $\mathrm{P}$ & 1.32 \\
\hline $\mathrm{B}$ & 0.8 \\
\hline
\end{tabular}

\section{Plant chracteristics}

At harvest time (126 days after sowing), the following parameters were recorded:

6.1. yield and seed characteristics: foliage yield (ton/fed), total yield (ton/fed), seed weight (g/plant), seed weight $\left(\mathrm{g} / \mathrm{m}^{2}\right)$, weight of 1000 seeds, seed yield (ton/fed), harvest index $(\%)$, and seed water content $(\%)$.

6.2. water characteristics Qiunoa water requriments $\left(\mathrm{m}^{3} / \mathrm{fed}\right)$, and irrigation water use efficiency (water productivity), $\mathrm{kg} / \mathrm{m}^{3}$.

\section{$\underline{\text { 7. Statistical analysis }}$}

All obtained data of the present study were, statistically, analyzed according to the design used by the Statistix (2019) computer software program and were tested by analysis of variance. The revised least significant difference test at 0.05 level of probability was used to compare the differences among the means of the various treatment combinations as illustrated by Duncan (1955) and Gomez and Gomez (1984). 
RESULTS AND DISCUSSION

1. Quinoa yield and seed characteristic

The irrigation regime treatments had a highly significant effect on foliage and total yield (Table 4). The highest values were attained at $100 \%$ of the $\mathrm{ET}_{\mathrm{o}}$ irrigation regime. It accounted for 2.82 and 2.72 times increase over the rainfed irrigation treatment, respectively. Seed weight per plant and seed weight per $\mathrm{m}^{2}$ reached a maximum value at $100 \%$ of $\mathrm{ET}_{0}$. It increased by about 216.70 and $216.68 \%$ over the rainfed irrigation regime, respectively. There were no significant differences between 100 and $80 \%$ of $\mathrm{ET}_{0}$ treatments. Seed weight per plant was 10.185 and $8.781 \mathrm{~g} /$ plant at 100 and $80 \%$ of $\mathrm{ET}_{0}$, respectively; as well, seed weight per $\mathrm{m}^{2}$ was 203.69 and $175.62 \mathrm{~g} / \mathrm{m}^{2}$ at 100 and $80 \%$ of $\mathrm{ET}_{0}$, respectively. The weight of 1000 - seeds reached the highest value at $60 \%$ of the $\mathrm{ET}_{0}$ irrigation regime ( $3.43 \mathrm{~g})$. It increased by $18.28 \%$ over the rainfed irrigation regime. Seed yield per fed recorded the highest value at $100 \%$ of the $\mathrm{ET}_{0}$ irrigation regime $(0.616$ ton/fed). The increase over the rainfed irrigation treatment was $155.56 \%$. There were no significant differences between irrigation at 100 and $60 \%$ of the $\mathrm{ET}_{0}$ irrigation regime as shown in Table 4 and Figure 1. The harvest index reached the highest value at $40 \%$ of $\mathrm{ET}_{0}$ irrigation treatment $(45.81 \%)$. It increased by about $39.96 \%$ over the rainfed irrigation regime $(32.73 \%)$. In addition, the seed water content reached its maximum value at $100 \%$ of $\mathrm{ET}_{0}$ treatment and decreased with other irrigation regimes (Table 4).

Table (4). Quinoa seed yield and seed quality as affected by irrigation regime

\begin{tabular}{ccccccccc}
\hline $\begin{array}{c}\text { Treatments } \\
\text { \% of ET }\end{array}$ & $\begin{array}{c}\text { Foliage yield } \\
\text { ton/fed }\end{array}$ & $\begin{array}{c}\text { Total } \\
\text { yield } \\
\text { ton/fed }\end{array}$ & $\begin{array}{c}\text { Seed } \\
\text { weight } \\
\text { g/plant }\end{array}$ & $\begin{array}{c}\text { Seed } \\
\text { weight } \\
\mathbf{g} / \mathbf{m}^{2}\end{array}$ & $\begin{array}{c}\text { Weight } \\
\text { of 1000- } \\
\text { seeds(g) }\end{array}$ & $\begin{array}{c}\text { Seed yield } \\
\text { ton/fed }\end{array}$ & $\begin{array}{c}\text { Harvest } \\
\text { Index, \% }\end{array}$ & $\begin{array}{c}\text { Seed } \\
\text { moisture } \\
\text { content, \% }\end{array}$ \\
\hline $\mathbf{1 0 0}$ & $1.171 \mathrm{a}$ & $1.787 \mathrm{a}$ & $10.185 \mathrm{a}$ & $203.69 \mathrm{a}$ & $3.32 \mathrm{a}$ & $0.616 \mathrm{a}$ & $35.23 \mathrm{ab}$ & $11.16 \mathrm{a}$ \\
\hline $\mathbf{8 0}$ & $0.899 \mathrm{~b}$ & $1.419 \mathrm{~b}$ & $8.781 \mathrm{ab}$ & $175.62 \mathrm{ab}$ & $3.33 \mathrm{a}$ & $0.520 \mathrm{ab}$ & $37.10 \mathrm{ab}$ & $10.68 \mathrm{a}$ \\
\hline $\mathbf{6 0}$ & $0.795 \mathrm{~b}$ & $1.310 \mathrm{~b}$ & $8.658 \mathrm{ab}$ & $173.15 \mathrm{ab}$ & $3.43 \mathrm{a}$ & $0.515 \mathrm{ab}$ & $39.70 \mathrm{ab}$ & $9.50 \mathrm{ab}$ \\
\hline $\mathbf{4 0}$ & $0.483 \mathrm{c}$ & $0.887 \mathrm{c}$ & $6.868 \mathrm{~b}$ & $137.36 \mathrm{~b}$ & $2.77 \mathrm{a}$ & $0.404 \mathrm{bc}$ & $45.81 \mathrm{a}$ & $10.01 \mathrm{ab}$ \\
\hline Rainfed & $0.415 \mathrm{c}$ & $0.656 \mathrm{c}$ & $3.216 \mathrm{c}$ & $64.32 \mathrm{c}$ & $2.90 \mathrm{a}$ & $0.241 \mathrm{c}$ & $32.73 \mathrm{~b}$ & $8.14 \mathrm{~b}$ \\
\hline
\end{tabular}

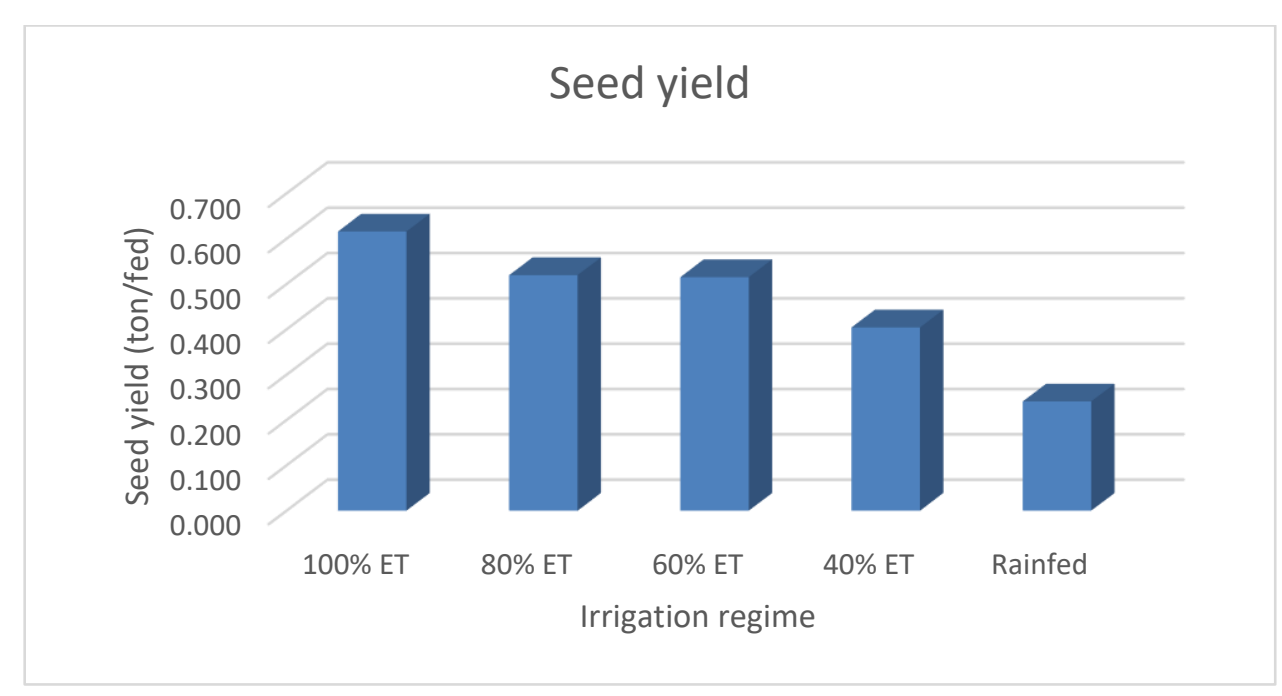

Figure (1): Effect of irrigation deficit on seed yield of quinoa

\section{. Quinoa water requirements and water productivity}

The water use efficiency calculated as:

$$
\begin{aligned}
& \operatorname{IWUE}\left(\mathrm{kg} / \mathrm{m}^{3}\right)=\frac{\text { Seed Yield }(\text { ton } / \text { fed })}{\mathrm{TAW}\left(\mathrm{m}^{3} / \mathrm{fed}\right)} \\
& \operatorname{CWUE}(\mathrm{kg} / \mathrm{mm})=\frac{\text { Seed Yield(ton } / \text { fed })}{\operatorname{ETc}(\mathrm{mm} / \mathrm{fed} / \text { season })}
\end{aligned}
$$

The total applied water (TAW) were 931.4, 796.6, 658.0, 523.3, and $285.6 \mathrm{~m}^{3} / \mathrm{fed}$ for irrigation treatments of $100,80,60$, and $40 \%$ of $\mathrm{ET}_{0}$ and rainfed irrigation, respectively (Table 5). The calculated crop evapotranspiration reached 229.0, 183.2, 137.4, 91.6, and $50.2 \mathrm{~mm} /$ season, respectively. The irrigation water-use efficiency (IWUE) or water productivity (WP) as $\mathrm{kg}$ seeds $/ \mathrm{m}^{3}$ of applied water reached the values of 0.681 , $0.655,0.806,0.778$, and $0.712 \mathrm{~kg} / \mathrm{m}^{3}$ for 100,80 , 
60 , $40 \%$ of $\mathrm{ET}_{0}$, and rainfed treatments, respectively. The maximum value was obtanid for $60 \%$ of $\mathrm{ET}_{0}$ (Table 5 and Figure 2). The consumptive water-use efficiency (CWUE) reached its maximum value at $40 \%$ of the $\mathrm{ET}_{0}$ irrigation regime. Its values were $2.769,2.847$, $3.858,4.443$, and $4.053 \mathrm{~kg} / \mathrm{mm}$ of applied water, respectively. Irrigation at $60 \%$ of $\mathrm{ET}_{0}$ was the best treatment resulting in the highst water productivity (IWUE). It increased by about $13.20 \%$ over the rainfed irrigation treatment. At this treatment, it is possible to save about $273.4 \mathrm{~m}^{3} / \mathrm{fed}$ of applied water; which accounted for $29.35 \%$ of watersaving.

Table (5). Quinoa water requirements of Quinoa as affected by irrigation regime

\begin{tabular}{ccccc}
\hline $\begin{array}{c}\text { Treatments } \\
\text { \% of ET }\end{array}$ & $\begin{array}{c}\text { ETc } \\
\text { mm/season }\end{array}$ & $\begin{array}{c}\text { TAW } \\
\mathbf{m}^{\mathbf{3}} / \mathbf{f e d}\end{array}$ & $\begin{array}{c}\text { CWUE } \\
\mathbf{k g} / \mathbf{m m}\end{array}$ & $\begin{array}{c}\text { IWUE } \\
\mathbf{k g} / \mathbf{m}^{\mathbf{3}}\end{array}$ \\
\hline 100 & 229.0 & 931.4 & 2.769 & 0.681 \\
\hline 80 & 183.2 & 796.6 & 2.847 & 0.655 \\
\hline 60 & 137.4 & 658.0 & 3.858 & 0.806 \\
\hline 40 & 91.6 & 523.3 & 4.443 & 0.778 \\
\hline Rain & 50.2 & 285.6 & 4.053 & 0.712 \\
\hline LSD 0.05 & & & $1.462 \mathrm{~ns}$ & $0.278 \mathrm{~ns}$ \\
\hline
\end{tabular}

TAW: Total applied water

CWUE: Consuming water use efficiency

IWUE: Irrigation water use efficiency $\quad$ ETc: crop evapotranspiration

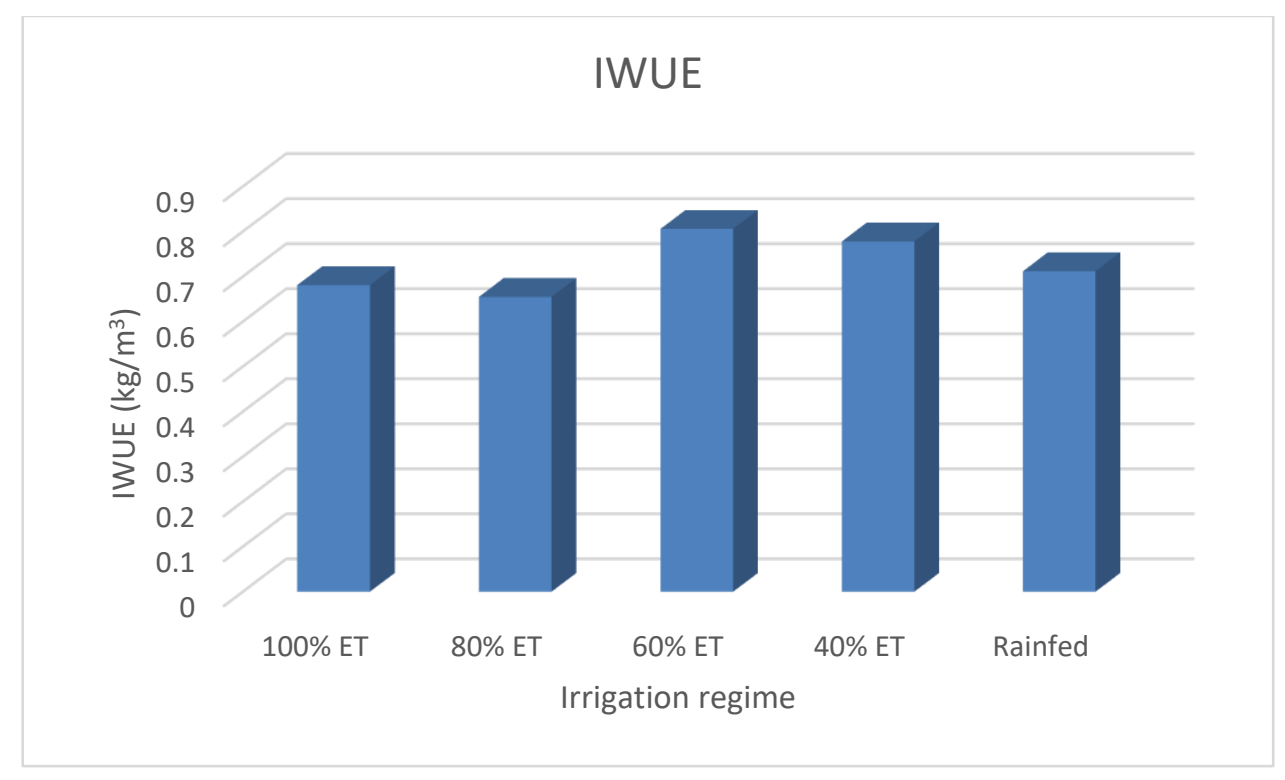

Figure (2). Effect of irrigation deficit on water productivity of quinoa

The present results indicated that if the farmers need the highest yield of quinoa, they must use $100 \%$ of $\mathrm{ET}_{0}$ for irrigation. However, if the farmers need the efficient use of irrigation water, they must use $60 \%$ of $\mathrm{ET}_{0}$ for irrigation. This treatment saves about $273.4 \mathrm{~m}^{3} / \mathrm{fed}$, but the seed yield may be reduced by about $19.61 \%$ of the maximum yield at $100 \%$ of $\mathrm{ET}_{0}$. Then the decision may be the comparison between the cost of saving water and the cost of reduced seed yield, the which is moor cost effective may be applied.

Deficit irrigation is defined as an optimization strategy in which irrigation is applied during the drought-sensitive growth stage of the crop (Geerts and Raes, 2009). In this regard, several studies were performed to find out the most sensitive stage of quinoa growth to water stress. (Jensen et al., 2000) did observe the yield reduction when water stress was applied during the flowering stage and grain filling stage, while application of water stress during the vegetative stage led to yield increase. In another study, Geerts et al. (2008) indicated that the milky grain stage of quinoa was most sensitive to water stress, followed by the flowering stage. Furthermore, Hirich et al. (2014) performed field trials in Morocco and 
concluded that the most tolerant stage to water stress is the vegetative stage, and deficit irrigation is most efficient when it is applied during this stage. Plant responses and mechanisms for dealing with low water availability can be divided into two major categories that are stress avoidance and stress tolerance (Claeys and Inze, 2013). Quinoa can tolerate water stress through a branched and deep root system (Alvarez-Floreset al., 2014).

Quinoa can resist water deficit based on its intrinsic low water requirement. Its skill to resume rapidly to its former photosynthetic level, and its specific leaf area after a period of water stress (Jacobsen et al., 2009; Jensen et al., 2000). This ability makes it suitable for growing in arid and semi-arid regions, where there is less water available for irrigation and farmers need to rely on seasonal rainfall (Bhargava et al., 2006). Quinoa's grain is a rich source of minerals, vitamins, highquality oil, protein, and natural antioxidants (Vega-Gálvezet al., 2010). In recent years, the quinoa crop received a lot of attention, because of its adaptability to produce in unfavorable soils and under harsh climatic conditions (Garcia et al. 2003; Jacobsen et al., 2013, and 2015).

Comparing the result of this study with other studies performed at other places suggested that the farmers in semi-arid regions have to be cautious for cultivating quinoa, as the produced seed yield was significantly lower than that obtained in other places under field conditions using a higher amount of applied irrigation water. Water scarcity, low rainfall, depletion of groundwater, the occurrence of drought, and poor water management in semi-arid regions makes the water much more valuable. Quinoa is a good candidate crop for agricultural diversification because of its extraordinary tolerance to various environmental stress conditions like drought and soil salinity. Therefore, decision-makers can consider this fact before promotingfarmers to cultivate new untraditional crops such as quinoa as a new applied land-use type that tolerant to drought conditions.

Plant root systems are essential for adaptation against different types of biotic and abiotic stresses. Different root features such as fine root diameter, specific root length and area, root angle, and root density are useful for improving a plant's productivity under water-stress conditions (Wasaya et al., 2018). Forster et al., (2005) indicated that plants having higher root density (RD) could extract sufficient water. This concept corresponding with high water stress. According to the present result, the quinoa RD (calculated as root weight over the soil volume per plant, $\mathrm{g} / \mathrm{cm} 3$ ) indicating that one of the strategies of quinoa to overcome water stress is to increase its root growth (Alvarez-Flores et al, 2014). Variation in RD of different irrigation treatments showed that $\mathrm{RD}$ increased significantly by increasing deficit irrigation at all treatments.

The advantages of deficit irrigation may be:

1- This resulted in maximization of the water productivity with good crop quality,

2- Creates a less wetted environment for crops and decreasing the riskof some diseases (such as fungi) in comparison with full irrigation, and

3- Reduces the leaching of plant nutrients due to the reduction of waterleaching in the root zone, and lower requirements of fertilizerapplication as for full irrigation conditions

To obtain the deficit irrigation advantages, there are some restrictionssuch as:

1- Know which crops respond to water deficit, and 2- More information about the crop-sensitive growing stages.

The deficit irrigation can be successful if farmers take action to avoid the risk of soil salinization due to insufficient leaching of the root zone when irrigating with poor water quality.

Generally, taking into account extreme caution when applying insufficient irrigation without prior knowledge of the plant's response to the deficit of water, taking into account the addition of leaching needs to remove salts in the root zone depth.

\section{CONCLUSION}

The present study investigates the comparison between irrigation deficit and rainfed irrigation. The obtained results concluded that irrigation at $60 \%$ of the $\mathrm{ET}_{0}$ irrigation regime resulted in high water-use efficiency. The best effect of irrigation treatment was recorded with 80 and $60 \%$ of the $\mathrm{ET}_{0}$ irrigation regime resulting in the highest seed yield. Therefore, it is recommended to apply the irrigation rate of Quinoa at 80 or $60 \%$ of $\mathrm{ET}_{0}$ in regions that have such present conditions.

\section{REFERENCES}

Abou-Zaid, A.A., S.Y. El-Faham, and W.H. Emam (2012). Use of Quinoa meal to produce bakery products to Celiac and Autism Stuffs. Intern. J. Sci. and Res. 3, 1344-1354.

Alvarez-Flores, R., T. Winkel, A. Nguyen-ThiTruc, and R. Joffre (2014).Root foraging capacity depends on root system architecture and ontogeny in seedlings of three Andean Chenopodium species. Plant and Soil, 380(1-2): 415-428. https://doi.org/10.1007/ s11104-014-2105$\mathrm{x}$.

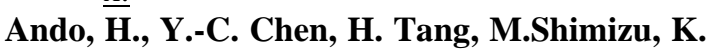
Watanabe and $T$. Mitsunaga (2002). 
Food Components in Fractions of Quinoa Seed. Food Science and Technology Research,8(1), 80-84. doi:10.3136/fstr.8.80

Ashraf, M.F. and M. Foolad (2007). Roles of glycine-betaine and proline in improving plant abiotic stress resistance. Environ. Exp. Bot., 59(2): 206-216.

Bhargava, A., S. Shukla, and D. Ohri (2006). Chenopodium quinoa-An Indian perspective. Industrial Crops and Products. 23:73-87.

Carter, M. R. and E. G. Gregorich (2008).Soil sampling and methods of Analysis. Second Edition. Canadian Soc. Soil Sci., Boca Raton, FL: CRC Press, 1264 pages.

Claeys, H., and D.Inzé (2013). The agony of choice: How plants balance growth and survival under water-limiting conditions. Plant Physiology, 162(4):1768-1779. https://doi.org/10.1104/pp.113.220921

Duncan, D.B. (1955).Multiple Range and Multiple F-Test. Biometrics, 11, 1-5.

Escuredo, O., M.I.G. Martín, G.W. Moncada, S. Fischer, J.M.H. Hierro (2014). Amino acid profile of the quinoa (ChenopodiumquinoaWilld.) using nearinfrared spectroscopy and chemometric techniques. J. Cereal Sci., 60: 67-74.

Food and Agriculture Organization of the United Nations (FAO) (2012). Food and Agriculture Organization of the United Nations - Statistics. Retrieved 2019 February 7 from http://faostat.fao.org.

Forster, B. P., W.T.B. Thomas, and $O$. Chloupek (2005). Genetic controls of barley root systems and their associations with plant performance. Aspects of Applied Biology, 73: 199204.

Garcia, M., D. Raes, and S.E. Jacobsen (2003). Evapotranspiration analysis and irrigation requirements of quinoa (Chenopodium quinoa) in the Bolivian highlands. Agricultural Water Management, 60(2):119-134. https://doi.org/10.1016/S0378-3774 (02)00162-2

Geerts, S., and M. Garcia (2012). Crop yield response to water. Irrigation and drainage paper. FAO 66. Page 230.

Geerts, S. and D. Raes (2009). Deficit irrigation as an on-farm strategy to maximize crop water productivity in dry areas. Agricultural Water Management, 96(9):1275-1284. https://doi.org/10.1016/j. agwat.2009.04.009

Geerts, S., D. Raes, M. Garcia, O. Condori, J. Mamani, R. Miranda, and J. Vacher. (2008). Could deficit irrigation be a sustainable practice for quinoa
(ChenopodiumquinoaWilld.) in the Southern Bolivian Altiplano?. Agricultural Water Management, 95(8):909-917. https://doi.org/10.1016/j.agwat.2008.02.01 $\underline{2}$.

Gomez, K. A. and A. A. Gomez (1984). STATISTICAL PROCEDURES FOR AGRICULTURAL RESEARCH. 2ed. AN INTERNATIONAL RICE RESEARCH INSTITUTE BOOK. JOHN WILEY \& SONS,

Hirich, A., R. Choukr-Allah, and S. E. Jacobsen (2014). The combined effect of deficit irrigation by treated wastewater and organic amendment on quinoa (ChenopodiumquinoaWilld.) productivity. Desalination and Water Treatment, 52(1012):2208-2213. https://doi.org/10.1080/19443 994.2013.777944.

Iqbal, M.A. (2015). An Assessment of Quinoa (Chenopodium quinoa, Willd.) Potential as a Grain Crop on Marginal Lands in Pakistan. American-Eurasian J. Agric. \& Environ. Sci., 15 (1): 16-23

Jackson, M. L. (1973). Soil chemical analysis. Prentice-Hall, of India private Limited New Delhi, P. 498.

Jacobsen, S.-E. , F. Liu, and C. R. Jensen (2009). Does root-sourced ABA play a role for regulation of stomata under drought in quinoa (Chenopodium quinoa, Willd.).Scientia Horticulture, 122: 281287.

Jacobsen, S. E., N. Nunez, C. R. Spehar, and C. R. Jensen (1998). Quinoa: A potential drought-resistant crop for the Brazilian savannah. Proc. of the Int. Conf. on Sustainable Agriculture in Tropical and SubtropicalHighlands with Special Reference to Latin America (SATHLA) [CDROM]. INT, Rio de Janeiro.

Jacobsen, S. E., M. Sørensen, S.M. Pedersen, and J. Weiner (2013).Feeding the world: genetically modified crops versus agricultural biodiversity. Agronomy for Sustainable Development, 33(4): 651-662. https://doi.org/10.1007/s13593-013-0138-9

Jacobsen, S. E., M. Sørensen, S. M. Pedersen, and J. Weiner (2015). Using our agrobiodiversity: plant-based solutions to feed the world Agronomy for Sustainable Development, 35: 1217-1235. https://doi.org/10.1007/s13593-015-0325y.

Jensen, C. R., S. E. Jacobsen, M. N. Andersen, N. Nunez, S. D. Andersen, L. Rasmussen, and V. O. Mogensen, (2000). Leaf gas exchange and water relation characteristics of field quinoa 
(ChenopodiumquinoaWilld.) during soil drying. European Journal of Agronomy, 13(1): 11-25. doi.org/10.1016/S1161-0301 (00)00055-1.

Koehler, P., H. Wieser, and K. Konitze (2014). Celiac Disease and Gluten Multidisciplinary Challenges and Opportunities,pp. 173-213. Academic Press.UK.

Maradini-Filho, A.M., M.R. Pirozi, J.T.S. Borges, H.M.P. Santana, J.B.P. Chaves, J.S.D. Reis-Coimbra, (2017). Quinoa: nutritional, functional, and anti-nutritional aspects. Crit. Rev. Food Sci. Nutr., 57: 1618-1630.

Naz, H., N.A. Akram, and H. Kong (2020). Assessment of secondary metabolism involvement in water stress tolerance of quinoa (chenopodiumquinoawilld) Subjected to varying water regimes. Pak. J. Bot., 52(5): 1553-1559.
Richards, L.A. (ed.) (1972). Diagnosis and Improvement of Saline and Alkaline Soils. U.S. Dept. of Agric., Agric. Handbook No. 60

Statistix (2019). Analytical Software, version 10.0. Vega-Gálvez, A., M. Miranda, J. Vergara, E. Uribe, L. Puente, and E. A. Martínez (2010). Nutrition facts and functional potential of quinoa (Chenopodiumquinoawilld.), an ancient Andean grain: A review. Journal of the Science of Food and Agriculture, 90(15): 2541-

2547.https://doi.org/10.1002/jsfa.4158.

Wasaya, A., X. Zhang, Q. Fang, Z. Yan. (2018).Root phenotyping for drought tolerance: A review. Agronomy, 8(11): 241. https://doi.org/10.3390/agron omy 81 10241. 


\section{الملخص العربي}

أثر نقص الري على المحصول والانتاجية المائية للكينوا

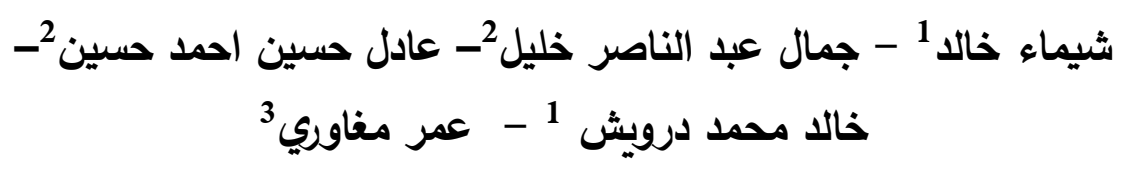

1 قسم تكنولوجيات الأراضى و المياه - معهد بحوث زراعة الأراضى القاحلة - مدينة الأبحاث العلمية و التطبيقات

$$
\text { التكنولوجية - برج العرب - الإسكندرية }
$$

2 قسم الأراضي و الكيمياء الزراعية - كلية الزراعة سابا باشا - جامعة|لإسكندرية

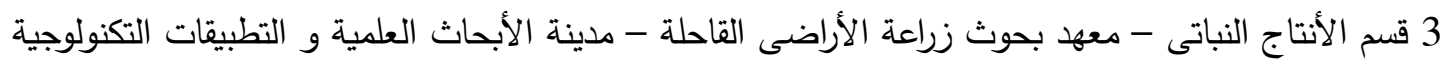

كبرج العرب- الإسكندرية

يهدف البحث الحالي إلى دراسة تأثير نقص الري على الكينوا صنف (chenopodium quinoa Willd) Chipaya

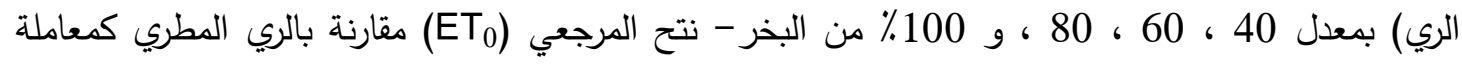

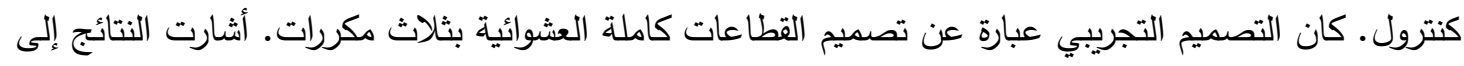
أن نظام الري (نقص الري) له تأثير معنوي على إنتاجية الكينوا. تم تسجيل أفضل تأثير لنظام الري على محصول

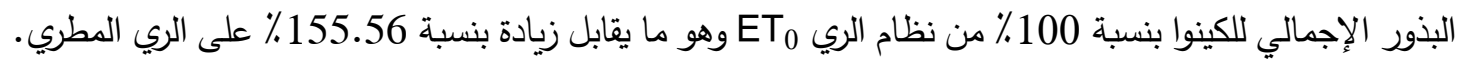

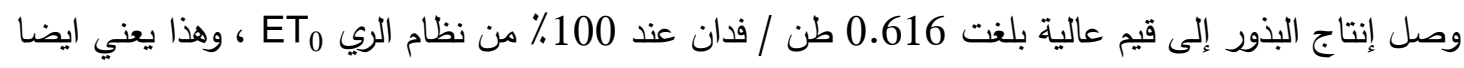

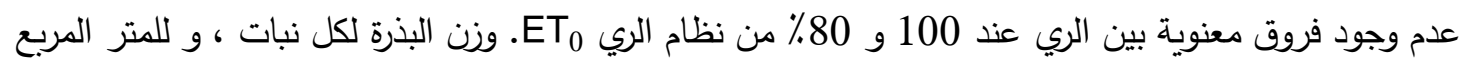

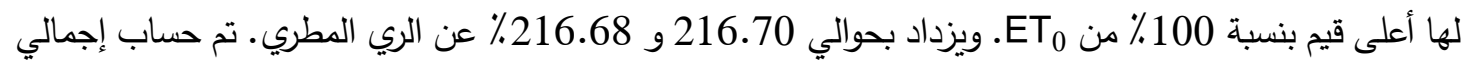
المياه المضافة (TAW) بـ 931.4 و 796.6 و 658.0 و 523.3 و 285.6 متر مكعب / فدان لمعاملات

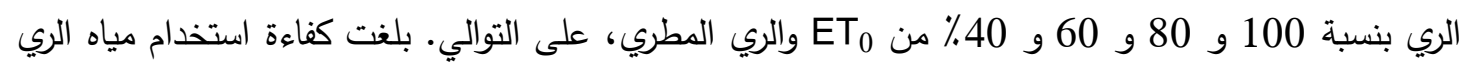
(IWUE)

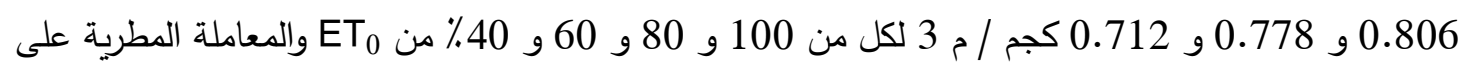

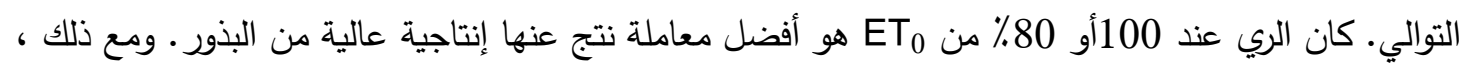
أدى الري بنسبة 60 \% من ETO إلى إنتاجية مائية عالية. 